\title{
60 Years from Birth of Academician F.G. Filip
}

\author{
Ioan Dziţac, Mişu-Jan Manolescu, Horea Oros, Emma Văleanu
}

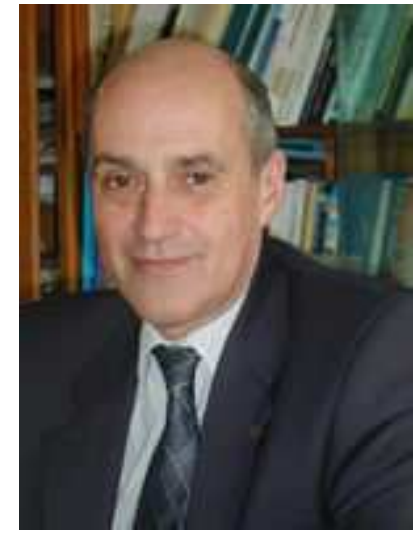

"To whom it may concern ...

Dr. Filip has shown himself to be a very innovative and productive researcher whose papers are equivalent in quality and cutting-edge findings to those from the best research organizations of the world. Witness his publications in Automatica, Computers in Industry and other leading journals in the field. The establishment of Dr. Filip's stature as an internationally recognized researcher in his field and the acceptance of his work are shown by the large number of international conferences where he has served as session chairman and/or program committee member and many invited seminars he has presented in other countries... ${ }^{1}$,
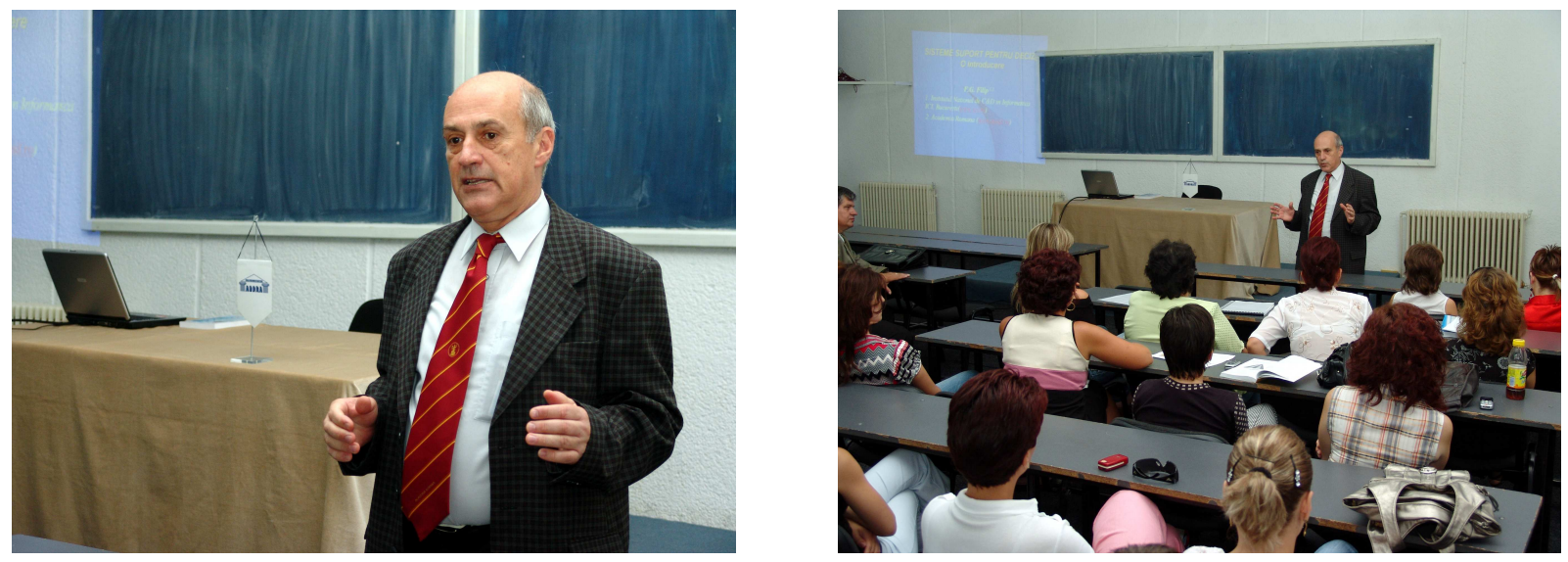

\section{Introduction}

Born in Bucharest on the $25^{\text {th }}$ of July 1947, the academician Florin Gheorghe Filip, Editor in Chief of our journal (IJCCC), turns 60, this is why the operative/executive editorial staff of IJCCC wants to

\footnotetext{
${ }^{1}$ Prof. Theodore J. Williams

Professor of Engineering and Director, Purdue Lab. for Applied Industrial Control, Purdue University;

Former President of Instrument Society of America;

Former President of the American Federation of Information Processing Societies;

Chairman of IFAC/IFIP Task Force on "Architecture for Enterprise Integration" (August 1994)
} 
dedicate this short biographical-sketch in order to pay him homage.

His life is under the sign of creation in science, of generosity in his relationship with his co-workers, of his innovative courage in the coordination of the projects he has worked on, of the stimulating energy in the community he has worked for a longer period of time or just collaborated occasionally, and under the sign of modesty in his relation with other people with whom he was in contact.

Most of the people who know him through their work acknowledge his good and stimulating effects on their work or career. In order to show him respect, lots of similar journals dedicated him special numbers in this period.

Not willing to be in competition with other journals, we would like to dedicate only this short biographical sketch, but in No 4/2007 of IJCCC, we are going to publish some of the scientific articles of authors who expressed their wish to dedicate them to Academician Filip when he turns his 60.

We will present in this paper a short digest of the biography and work of F.G. Filip

\section{Opera omnia}

Prof. F. G. Filip is author/coauthor of 6 monographs published in Ed. Tehnica (http://www.edituratehnica.ro/) and he is editor/coordinator of 9 contribution volumes published in Ed. Tehnica, Romanian Academy Editing House (www.ear.ro), Ed. Expert and Elsevier.

Also, he publish more than 200 scientific papers in several international journals (Computers in Industry, IFAC J. Automatica, IFAC J Control Engineering Practice, Large Scale Systems, J. of Human Systems Management, Systems Analysis, Modeling and Simulation, Studies in Informatics and Control etc.) and some contribution volumes printed in the Publishing Houses: Pergamon Press, North Holland, Chapmann and Hall, Springer, Kluwer, Ed. Tehnica and Ed. Academiei Române. More than 50 articles of F.G. Filip are registered in Thomson ISI Web of Knowledge Database and 22 in SCOPUS and ELSEVIER Databases.

\section{Academic qualifications, scientific titles and professional positions}

F.G. Filip graduated the Faculty of Automatics, University Politehnica of Bucharest, obtaining the Engineer Diploma in 1970 and received his Ph. D (1982) in Automatics (Electrical processes automation field).

Later on, he participated at several courses of professional forming and improvement: "Complex informatics systems, tele-processing systems" (Sweden, at the Universities from Goeteborg, Uppsala, Malmoe, Stockholm 1974); "Research and technology management" (Germany, Fraunhofer IITB Karlsruhe, 1995); "Decisional systems" (Germany, Fraunhofer FIRST, Berlin, 1998) etc.

F.G. Filip is Corresponding Member of the Romanian Academy since 1991 and Full Member of the Romanian Academy since 1999. since 2000 acad. Filip is Vice- President of the Romanian Academy.

Last professional titles obtained by F.G. Filip are First Degree Researcher (1990) and University Professor (1998).

He jobs and positions held is following: Engineer (1970-1976); Scientific researcher (1976-1979); Main researcher III-(1979-1990); Head of the research laboratory (1985-1991); Main researcher I (1990); Director- through contest at ICI (1991-1997); Scientific Director- responsible with the international cooperation (1997-2001); President of the Scientific Committee (1995-2003); Vice-President of the Romanian Academy (2000-now).

\section{Awards, diplomas and distinctions}

F.G. Filip received the following award, diplomas and distinctions: 
1. "Grigore Moisil" Award and the Diploma "Man of the Year 1999" granted by INFOREC (The Association of Economical Informatics).

2. Doctor Honoris Causa of "Lucian Blaga" University, Sibiu (2000).

3. The Award "COPY RO for informatics" for the year 2003 for the monograph "Computer aided decision: base methods and techniques" (Ed. Tehnica, Bucharest, 2002, in Romanian).

4. Honorary professor of "Dunarea de Jos" University, Galati (from 2003).

5. Excellency Diploma "The most prominent Romanian personality of the decade in IT\&C" granted by ARIES (Romanian Association for the Electronically and Software Industry).

6. Honorary member of the Romanian Technical Sciences Academy - ASTR (www.astr.ro) (from 2006).

7. Honorary member of Moldavian Academy of Science (from 2006).

8. Decorated with the National Order "Loyal Service" in rank of "Great Cross" (granted by the Romanian President on 30.11.2000)

9. Honorary Citizen of Campeni City(2002).

\section{Research activities}

Research projects coordination regarding:

- The elaboration of the dimensioning methods for the equipments configurations;

- Participating on projects regarding the informatics systems in industry;

- Researches regarding the designing of discrete automate systems;

Research projects coordination regarding:

- Hierarchical leadership methods and hierarchical compute methods;

- Real time hierarchical informatics systems;

Applicative projects coordination regarding:

- Implementation and design of real time informatics systems and decision support systems (DSS);

- Contribution to the design of the DISPECER SSD (exported in 1996)

Researcher leadership in conceiving SSD with combined knowledge (numerical models and artificial intelligence elements)

ICI Teams coordination participating to projects/networks of excellence ("Network of excellence"NOE) or international "Working group"-WG:

- For the EC-PECO program: ESATT + (“European Science and Technology Transfer Network+”),

- For the INCO program: a) NOE AMETMAS (CP 96-26), b) INIDS ("Information Dissemination in European RTD”- IC-1030) 
- For the ESPRIT program: ORBIT ("Object-oriented Decision Assistance for Continuous Operations Scheduling and Coordination”-24487), NOE ICIMS (9251), Si E (Simulation Europe) WG (cod: 8467)

General coordination of the research activities from ICI.

Coordination of the RNC (National computer network for research) Project Accomplishment, the first Romanian network connected to the Internet (1993).

Coordination of the projects for introducing the informatics in the cultural institutes (libraries, museums).

Founding (in 1989) and coordination of the international journal "Studies in Informatics and ControlSIC" (http://www.ici.ro/ici/revista/sic.html) (registered from 1995 the IEEE INSPEC Database, indexed in ISI Web of Knowledge, the first Romanian journal that had an on-line version from 1992).

Founding (in 2006) and coordination of the international journal "International Journal of Computers, Communications and Control-IJCCC" (http://www.journal.univagora.ro).

Participating to some ICI international projects: a) INTERBIT ("Interbalkan Net of Technology"IST 1999-14022), b) MobiTech ("European SME Challenge in Mobile Telecom Technologies"-IPS1999-50125), c) IDEALIST 5FP, d) PROLEARN (as "associated partner")

Coordination of the following Romanian Academy Sections:

- Technical sciences

- Geological sciences

- Sociological, juridical and economical sciences

- Informatics Science and Technology

Managerial coordination of the Romanian Academy Library (BAR)

Supervision of the Construction Activities at the Romanian Academy Library

Coordination of two fundamental projects of the Romanian Academy

- Informational Society - Knowledge Society (2001-2002)

http://www.academiaromana.ro/pro_pri/pag_com01socinf_prpri.htm

- Inter-disciplinary Program for preventing the major risks phenomenon at a national scale (2004-2005) http://www.icmpp.ro/institute/P_Fundam_AR.htm

Coordination of four international projects of the Romanian Academy:

- ForSociety - "Laying the Foundations for an ERA-NET on Foresight and Society" (contract ERASCT-2003-003231)

- ROINTERA - "Romanian Research Community Integration in the European Research Area" (contract INCO-CT-2003-510469), (www.rointera.ro)

- ROMOB - "Romanian Mobility Center” (contract FP 6 - 513461)

- ForSociety - "Transnational Foresight ERA Net” (http://195.251.117.130/ForSociety/partners/index.html)

Coordinator of projects: The programs EC-PECO, ESPRIT, COPERNICUS, IST of UE

The responsible of the Romanian teams from ICI at 10 projects/networks of excellence/workgroups (1993-2000: see the above no. 8) and at 2 projects of the Romanian Academy in FP6 (2003-): a) ROINTERA (NCO-CT-2003-510469), b) ForSociety (ERANet 011832)

Evaluator: 1992 (in the first team with invited experts from the Central and East Europe), 1996, 1999, 2004, 2005.

Member in : 
- Program Committee of the IST ("Information Society Technologies") research program of UE (1999-) national representative - named.

- Consultative Committee of the European Committee in the priority domain IST from FP6 (ISTAGInformation Society Technologies Advisory Group) (invited directly by the European Committee) (2003-2004)

NATO Science for Peace

- Associate member of the Sub-Committee Computer Networking (2000-2001) (selected by NATO)

CDI National Program

- Member of the Consultative Board for Research - Development - Innovation (1992-) and General Secretary (1998-) Member of the "Informatica" 5th Committee of the Consultative Board (from 1991), president of the "Informatica" 5th Committee (1993-1994) and vice-president (from 1995)

Romanian Academy Grants (GAR)

- Vice-President of the GAR Committee (1995-2007)

Romanian Academy priority and fundamental programs

- Coordinator of the project "Informational Society - Knowledge Based Society" http://www.academiaromana.ro/pro_pri/pag_com01socinf_prpri.htm (2001-2002)

- Leadership of the program "Major risk phenomenon and processes at national scale" http://www.icmpp.ro/institute/Contributii_stiintifice.htm (2004-2005)

\section{Didactical activities}

Doctorate guidance at

- UPB (University Politehnica of Bucharest), Faculty of Automatics - specialization "Automatics" (from 1993) - 8 finalized doctorates from which one is made in association with Franche Conte University)

- Romanian Academy - specialization “Computer Sciences" (from 2002)

Professor of "Applied informatics" at "Valahia" University, Targoviste (1998-2001) courses of:

- "Artificial Intelligence"

- "Computer aid decision"

- “Computer aid enterprise engineering” (master level)

Visiting Professor at

- University POLITehnica of Bucharest, Faculty of Mechanics (Mecatronica Department). Course: "Expert Systems" (1998)

- Hyperion University of Bucharest (1999-2003). Courses of: a) "Computer aided decisions" and b) "Artificial Intelligence"

- Agora University (2006- now) "Decision Support Systems" 
Master courses at:

- "Lucian Blaga" University Sibiu. Course: "Industrial Management” (1998)

- UPB-CPRU: Course: "Enterprise re-engineering" (1998) and "Computer aided Decision"(2005, 2006)

- University of Bucharest, Faculty of Letter. Course: "Computer aided Decision” (2004)

- ASE Bucharest. The modules "Computer aided Decision" from the course "Project Management" (2000)

- Ecole Centrale de Lille (France, 2006)

\section{Member in the editorial staff of some scientific journals/conferences}

Member in International program committees (IPC) at more than 50 international conferences and congresses from Europe, SUA, South America, Asia and Africa.

Member in the editorial board of the following journals:

1. SAMS (Systems Analysis, Modeling and Simulation) (Taylor and Francis) (1993-2004)

2. International J. of Critical Infrastructures (Interscience Publishers: www.interscience.com ) (2004)

3. Computer Journal of Moldova, Chisinau (1993), Information Technologies and Control (ISSN 1312-2622), Sofia (din 1998)

4. Information Technologies and Control, Sofia (2003)

5. ROMJIST (Romanian Journal of Information Science and Technology) of the Romanian Academy

6. Studies in Informatics and Control -SIC (founder and chief-editor, from 1989)

7. International Journal of Computers, Communications and Control (http://www.journal.univagora.ro/)chief-editor (from 2006)

8. Control Engineering and Applied Informatics (http://www.upg-ploiesti.ro/srait/publicatii.html)

9. Romanian Journal of Informatics and Automatics (http://www.ici.ro/ici/revista/ria.html): founder

10. Romanian journal of automatics (http://www.ipa.ro/web3-8RE.html)

Invited at conferences and seminars at universities and research institutes from: England (1984), Austria (1996), Brazil (1995), Chile (2004), China (1983, 1988, 2006), France (1992, 2006), Germany (1991), Kuwait (1986), Moldova Republic (1995, 2006), Sweden (1970), Tunisia (1998).

\section{Member in professional organizations}

- IFAC ("International Federation of Automatic Control"): Vice-President of the Technical Committee (TC) 5.4 "Large-Scale Complex Systems", http://www.academiaromana.ro/ifac/ifac_tc54.htm), (1998-2002), President of TC 5.4 (2002- 2005), confirmed for a new mandate (2005-2008)

- Founder Member of SiE (Simulation Europe) (1993-1997) 
- Honorary member of ATIC (Association for communication and informatics technology, from 1996) (www.atic.ro)

- Romanian forum for the informational society - Committee of the Romanian Academy, Executive president (from 1997)

- http://www.academiaromana.ro/forum_info/fpsc.htm

- SRAIT (Society of automatics and technical informatics), founder member (1992), Vice-President (1992-2001), now member of the Director Committee (http://www.upg-ploiesti.ro/srait/comitet.html)

- Member of IFAC - IFIP ("International Federation of Information Processing") Task-Force "Architectures for Entreprise Integration" (from 1995)

- Honorary Member of PITCH ("Association For the Promotion of International Technological Cooperation for Humanistic Ends"-) (2000-2006)

\section{Bibliography}

[1] Corina Pascu, F G Filip (Eds). (2005). Visions on Information Society Future in an Enlarged Europe, Ed Academiei, Bucharest.

[2] Filip. F.G. (2004). Decision Support Systems, Ed Tehnica, Bucharest.

[3] Filip, F.G. (2002). Computer aided Decision. Ed Tehnica, Bucharest

[4] Filip F.G., Dumitrache I., Iliescu, S.S. (Eds) (2002). Large Scale Systems: Theory and Applications 2001 (LSS’01). Elsevier Science Ltd. (Pergamon), Oxford.

[5] Filip F.G. (coordinator) (2001). Informational Society - Knowledge Society. Ed. Expert, Bucuresti.

[6] Filip F.G., Boldur B. (1999). Industrial informatics: new paradigms and applications, Ed. Tehnica.

[7] Filip F.G. (1998). Optimization models with sparse matrices and relatively constant parameters. Systems Analysis Modeling and Simulation, 33, 407-430.

[8] Filip F.G., Alexandru A. and Socol I. (1997). Technology management and international cooperation: several success stories. J. Human Systems Management, 16, 223-229.

[9] Filip F.G., Neagu G. and Donciulescu D. (1996). DSSfM: from technology to decision making. In Proceedings 14th IFAC World Congress, San Francisco Vol B, 367-372.

[10] Filip F.G. (1995). IT culture dissemination in Romania: experiments and achievements. In A. Inzelt and R. Coenen (Eds.) Knowledge Technology Transfer and Forecasting, Kluwer Academic, Dordrecht, 149 - 160.

[11] Filip F.G. (1995). Towards more humanized DSS. In: L.M. Camarinha Matos and H. Afsarmanesh (Eds.) Balanced Automation Systems: Architectures and Design Methods. Chapman \& Hall, London, 230 - 240.

[12] Filip F.G. (1994). Evolutions in systems analysis, modeling and simulation in Computer based industrial automation, Systems Analysis, Modeling and Simulation, 15, 135 - 149.

[13] Filip F.G. and Neagu G. (1993). CIM in continuous and discrete manufacturing: object-oriented generic modeling, IFAC J.Control Eng. Practice, 1(5), 815 - 825. 
[14] Filip F.G. (1992). System analysis and expert systems techniques for operative decision-making. In: A. Sydow (Ed.), Computational Systems Analysis: Topics and Trends, ELSEVIER, Amsterdam, $285-304$.

[15] Filip F.G. (1988), Operative decision-making in the process industry. In: Preprints, 12th IMACS World Congress, Paris, vol.4, 523 - 525.

[16] Guran M. and Filip F.G. (1986). Hierarchical and Real Time Systems with distributed data processing. Ed Tehnica, Bucuresti.

[17] Filip F.G. and Donciulescu D.A. (1983). On on-line direct dynamic coordination method in process industry, IFAC J. Automatica, 19(1), (Pergamon Press , Oxford), 317 - 320.

[18] Filip F.G., Neagu G. and Donciulescu D. (1983). Job shop scheduling optimization in real time production control. Computers in Industry, 4(4) (North Holland, Amsterdam), 395 - 403.

[19] Filip F.G., Donciulescu D., Muratcea M., Oraseanu L. and Predoiu D. (1980). Hierarchical control of large-scale chemical and metallurgical systems. In A. Titli and M. G. Singh (Eds.). Large Scale Systems: Theory and Application. Pergamon Press, Oxford, 563 - 575.

[20] http://www.ici.ro/ici/revista/sic.html

[21] http://www.journal.univagora.ro/

[22] http://www.ici.ro/ici/homepage/filipf.html

[23] http://www.academiaromana.ro/cv2006/birou_vice02Filip.htm

[24] http://romania-on-line.net/whoswho/FilipFlorinG.htm

Ioan Dziţac

Executive Editor of IJCCC

Agora University

Piata Tineretului 8, 410526 ORADEA

ROMANIA

idzitac@univagora.ro

Horea Oros

Technical Editor and editorial secretary of IJCCC

University of Oradea

Universitatii St. 1, 410087, ORADEA

ROMANIA

horos@uoradea.ro
Mişu-Jan Manolescu Managing Editor of IJCCC

Agora University

Piata Tineretului 8, 410526 ORADEA ROMANIA

rectorat@univagora.ro

Emma Văleanu

Webmaster and editorial secretary of IJCCC

Agora University

Piata Tineretului 8, 410526 ORADEA

ROMANIA

evaleanu@univagora.ro 